\title{
THE EFFECT OF ETHANOL ADDITION ON VEHICLE FUEL CONSUMPTION IN ECONOMIC TERMS - A REVIEW
}

\author{
Muhsin ${ }^{1}$ \\ ${ }^{1}$ Mechanical Engineering Education, Universitas Sebelas Maret Surakarta \\ Email: muhsin@student.uns.ac.id
}

\section{KEYWORDS}

alternative fuels

fuel oil

vehicles fuel consumption

renewable energy

\begin{abstract}
The technological development of the automotive sector is increasing, every year there is an increase in the production of motor vehicles in Indonesia. The increase in motorized vehicles will certainly have an impact on the use of fuel oil which is also increasing. Though fuel oil is a non-renewable fossil fuel, so that continuous use can lead to scarcity of fossil fuels someday. In addition to causing scarcity of fossil fuels, the increasing number of vehicles will also cause the surrounding environment to be increasingly polluted by the exhaust emissions from the combustion process of the motorized vehicles. Various alternatives are used as a mixture of fuels to reduce fuel consumption and vehicle exhaust emissions, such as ethanol, hydrogen, butanol, biodiesel, methanol etc. The purpose of this literacy study was to determine the effect of using ethanol on fuel consumption and its economic value. Based on the results of a study of literacy is known that the addition of ethanol does reduce the level of fuel consumption, However, if viewed from an economic perspective, the addition of ethanol has actually caused the purchase price of fuel to increase, this will certainly hinder the growth of the desire to use ethanol as an alternative source of fuel substitute by the people of Indonesia.
\end{abstract}

\section{INTRODUCTION}

Production of motorized vehicles from year to year has always experienced a significant increase. Indonesian Automotive Industry Association (Gaikindo) said that throughout 2018 there were 995,836 units of cars produced in Indonesia, while the number of production in 2017 was only 903,900. Based on these data, it can be concluded that there is an increase in the number of motorized vehicle production, especially for the four wheels, as many as 91,936 units of cars or by $10.2 \%$ (Gaikindo, 2018). Data on the number of production of motorized vehicles, especially cars, can be seen in the following table:

Table 1. Number of car production in Indonesia

\begin{tabular}{ccccc}
\hline \multirow{2}{*}{ Category } & \multicolumn{4}{c}{ Jan-Sep } \\
\cline { 2 - 5 } & $\mathbf{2 0 1 7}$ & $\mathbf{2 0 1 8}$ & $+/-$ & $\%$ \\
\hline Sedan & 21,925 & 20,694 & $-1,231$ & $-6 \%$ \\
\hline $4 \times 2$ & 504,336 & 553,308 & 48,972 & $10 \%$ \\
\hline $4 \times 4$ & 13,465 & 17,391 & 3,926 & $29 \%$ \\
\hline The bus & 1,642 & 2,633 & 991 & $60 \%$ \\
\hline Pick Up & 110,414 & 121,251 & 10,837 & $10 \%$ \\
\hline Truck & 62,581 & 89,075 & 26,494 & $42 \%$ \\
\hline Double cabin & - & - & - & - \\
\hline Affordable Energy Saving Cars & 189,537 & 191,484 & 1,947 & $1 \%$ \\
\hline Total & 903,900 & 995,836 & 91,936 & $10.2 \%$ \\
\hline & Source: Gaikindo (2018) & &
\end{tabular}


Based on data from BPH Migas there has been an increase in the amount of fuel oil consumption in Indonesia. In 2016 oil fuel consumption was 48655 005,967 ML, while in 2017 fuel consumption was 55400 $604,901 \mathrm{ML}$. From these data it can be seen that there was an increase in fuel oil consumption in Indonesia amounting to $6745598,934 \mathrm{M} \mathrm{L}$ or $13.86 \%$ (BPH MIGAS, n.d.). In line with the increase in the number of motorized vehicles, it will increase the use of fuel oil consumption (Muhsin, Wijayanto, \& Bugis, 2017).

Oil fuel itself is one of the non-renewable energy so that if usage is not restricted it is possible to cause the petroleum reserves to run out. The use of fuel oil continuously will eventually cause the fuel oil to experience scarcity and eventually it will run out, whereas in reality humans certainly cannot escape the use of fuel oil in their daily lives. Based on this, of course various alternatives are needed to reduce the impact of the use of fuel oil so that it does not reach scarcity and even run out of these natural resources.

However, the Indonesian government is still less consistent in exploring the potential of natural resources that exist in Indonesia, this is similar to what was revealed by Sunarto et al. (2008: 3), "Unfortunately the Indonesian government itself seems inconsistent in exploring and developing alternative renewable energy sources, such as micro-hydro, geothermal energy, solar energy, biomass, wind power and biofuels ". Biofuel can be an alternative fuel in reducing the impact of the increase in the number of motorized vehicles in Indonesia. One of the biofuels that are widely used in fuel mixtures is ethanol. The use of ethanol is very prospective for household sector fuel because it is liquid, clean if burned and has a heating value of $31.1 \mathrm{MJ} /$ kg (Sujono \& Kristiawan, 2009).

Ethanol is an organic compound consisting of carbon, hydrogen and oxygen, so that it can be seen as a derivative of a hydrocarbon compound that has a hydroxyl group with the formula $\mathrm{C}_{2} \mathrm{H}_{5} \mathrm{OH}$. Ethanol is a liquid, colorless, odorless, flammable and evaporating, can mix in water with all comparisons. Broadly speaking, the use of ethanol is as a solvent for organic and inorganic substances, basic ingredients of industrial vinegar, esters, methylated, acetaldehyde, antiseptics and as raw material for making meters and ethyl esters. Ethanol is also used to mix drinks and can be used as fuel (gasohol) (Wiratmaja, Kusuma, \& Winaya, 2011).

Fuels mixed with ethanol will increase the octane number of the fuel. Octane value is the ability of the fuel will / does not turn on itself (Kristanto, 2015: 70). Addition of 10\% ethanol will increase the octane number of a fuel by 5\% (Samuel Raja, Valan Arasu, \& Sornakuma, 2015). Ethanol is known as an environmentally friendly fuel, because it is clean from pollutant emissions. Ethanol can be made from plant raw materials containing starch such as cassava, sweet potatoes, corn, sago, and sugar cane drops.

Cassava, sweet potatoes, and corn are common food crops planted by the people in almost all regions of Indonesia, so that these types of plants are potential plants to be considered as a source of raw material for making ethanol or gasohol. In 1982 BPPT started the construction of an ethanol plant in Tulang Bawang with a capacity of 15,000 liters of ethanol/day which every day requires around 90 tons of raw materials for sweet potatoes and or cassava. The construction of the ethanol plant is intended as a premium substitution in the transportation sector, especially for areas that produce sweet potatoes and or cassava. In this regard, in 1883 the Agency for the Assessment and Application of Technology (BPPT) conducted an assessment of the use of ethanol and premium blends on vehicle fuels made from premium b roots in Indonesia (Ode \& Wahid, 1982).

Ethanol mixed with fuel will increase the octane number of the fuel. This increase in octane numbers will result in more perfect combustion that occurs in the cylinder. More perfect combustion is expected to be able to maximize engine performance so that fuel consumption will be reduced.

The purpose of this literature review is to find out how much the reduction in fuel oil consumption in vehicles when given an ethanol mixture, then reviewed in terms of economics whether with the addition of ethanol and a decrease in fuel consumption that occurs in the combustion process is efficient and economical review of the products produced based on the research data.

\section{RESEARCH METHODS}

Research is a research with systematic methodology of literature review. The systematic literature review is a preliminary study by reviewing previous studies. This article adopts a systematic literature review methodology from (Okoli \& Schabram, 2011). The steps taken in making a systematic literature review include 8 steps. The steps are to determine the purpose of the review literature, the provisions in conducting reviews, searching for literature, grouping literature, evaluating quality, extracting data, formulating findings, and writing the results of reviews. The results of each step are as follows: 


\section{Determine the purpose of the literature review}

The first step in the literature is to set goals and assess what is needed. Identify the goals and objectives to be carried out by the researcher. This article examines the effect of adding ethanol on fuel when viewed in terms of economics.

2. Make provisions in conducting reviews (protocol of the review)

The provisions in conducting literature before the search is to determine the database that will be used to find references and determine the keywords that will be used before the search begins. Here we use a database with the background effect of adding ethanol to fuel and using the keywords "ethanol", "fuel", "combustion", "SI Engine".

3. Search for literature (searching for the literature)

In this study we use a different database and digital library, including ScienceDirect, Google Scholar and other digital libraries.

\section{Group literature ( practical screen )}

Practical screens are also commonly referred to as networks for inclusion, at this stage researchers examine explicitly and consider which ones are included in the realm of review. This can be seen from the appropriate keywords, then read the scheming in the abstract section and conclusions. We review 10 papers from the database with the appropriate keywords. The following is a list of literature reviewed:

Table 1. Database data used

\begin{tabular}{lll}
\hline $\begin{array}{l}\text { Bibliographic } \\
\text { Database }\end{array}$ & Database URL & Total \\
\hline ScienceDirect & http://www.sciencedirect.com & 2 \\
\hline Google Scholar & https://scholar.google.co.id/ & 4 \\
\hline Other & $\ldots$ & 5 \\
\hline Total & & $\mathbf{1 1}$ \\
\hline
\end{tabular}

\section{Assessment of quality (quality appraisal)}

In this step, we need to explicitly describe the criteria for assessing which articles are of insufficient quality to be included in the review synthesis. The criteria for the paper we reviewed were the effects of adding ethanol to vehicle fuel consumption.

\section{Extracting data ( data extraction )}

After all the literature has been identified, we need to systematically extract the information that applies from each study. As a means of building a comprehensive understanding of the subject, the concept matrix is built focusing on computational thinking and educational robots. In this study, we extracted from each selected literature. The concept of this matrix provides information to verify quality criteria and to carry out synthesis. Furthermore, items are grouped into several findings. These findings are the results and systematic literature discussion.

7. Formulate findings ( synthesis of studies )

In this step involves combining the facts taken from the research, then grouping the findings based on the same theme, then formulating the findings of the effects of ethanol additions on the vehicle. This is also associated with the economic value of using ethanol.

8. Write review results ( writing the review)

The final stage of this review literature is to write the results of the discussion and the findings in the previous stage into an article

\section{RESULTS AND DISCUSSION}

In the internal combustion engine, mainly gasoline engines, combustion occurs due to 3 things, namely the presence of fuel, the appropriate ignition, and cylinder compression. If one of these conditions is not met, the gasoline engine will not be able to ignite. The quality of the fuel used for gasoline motors in Indonesia is divided according to the octane value. Octane value is the size of the fuel holding the knocking when the combustion step occurs in the cylinder, so the higher the octane number, the better the fuel and the combustion produced from the fuel is more perfect. 
In Indonesia, fuel for gasoline engines is divided into several types, including the ones

1. Premium (octane 88)

2. Pertalite (octane 90)

3. Pertamax (octane 92)

4. Pertamax turbo (octane 95)

However, as stated by the author at the outset that when the number of motor vehicles increases, it will be in line with the increase in the amount of fuel consumption. Then there needs to be an update or innovation related to this problem, one of which is the use of ethanol. Many studies reveal that the addition of ethanol will reduce vehicle fuel consumption.

\section{The effect of adding ethanol to fuel consumption}

Research conducted by (Wijayanto, Rohman, Hadisaputro, Bugis, \& Agung Pambudi, 2017) produce vehicle fuel consumption data with the addition of ethanol as follows:

\begin{tabular}{cc}
\hline \multicolumn{3}{c}{ Table 1. Research (Wijayanto et al., 2017) } \\
\hline \% ethanol & Fuel consumption (cc / cycle) \\
\hline 0 & 39.6 \\
\hline 5 & 38.4 \\
\hline 10 & 36.2 \\
\hline 15 & 36.8 \\
\hline 20 & 36.7 \\
\hline 25 & 35.5 \\
\hline 30 & 38.4 \\
\hline
\end{tabular}

The test uses a 4 cylinder kijang car with a 1290 cc engine capacity using gasoline. Based on these data, vehicle fuel consumption without an ethanol mixture of $39.6 \mathrm{cc} / \mathrm{cycle}$, then the most economical mixture with $25 \%$ ethanol (E25) addition of $35.5 \mathrm{cc} / \mathrm{cycle}$ or down by $10 \%$ from normal consumption.

Research conducted (Muhsin et al., 2017) produce fuel consumption data as follows:

Table 2. Research conducted by (Muhsin et al., 2017)

\begin{tabular}{cc}
\hline \% ethanol & Fuel consumption $(\mathbf{m l} / \mathbf{~ k m})$ \\
\hline 0 & 201,5 \\
\hline 5 & 181.8 \\
\hline 10 & 157.6 \\
\hline 15 & 150.0 \\
\hline 20 & 165,1 \\
\hline 25 & 166.7 \\
\hline 30 & 180.3 \\
\hline
\end{tabular}

Testing uses a 4 cylinder kijang car with a $1290 \mathrm{cc}$ engine capacity using pertalite fuel. Based on these data, vehicle fuel consumption without an ethanol mixture of $201.5 \mathrm{ml} / \mathrm{km}$, then the most economical mixture with $15 \%$ ethanol (E15) addition of $150 \mathrm{ml} / \mathrm{km}$ or down by $25.55 \%$ from normal consumption.

Other research conducted by (Sakthivel, Subramanian, \& Mathai, 2018) produced the following data :

Table 3. Research carried out (Sakthivel et al., 2018)

\begin{tabular}{cc}
\hline \multicolumn{2}{c}{ Fuel consumption } \\
\hline E0 & E30 \\
\hline 15.30 & 13.17 \\
\hline
\end{tabular}


Based on these data, there is a decrease in fuel consumption by $13.92 \%$ for the use of ethanol mixed into fuel. Based on these various studies, it can be concluded that the use of ethanol mixed with fuel can reduce vehicle fuel consumption significantly. This is certainly very helpful to reduce the amount of fuel consumption on a large scale if used properly.

\section{Ethanol causes the octane number to rise}

As stated earlier, to produce good combustion in a gasoline engine, it is necessary to pay attention to the conditions, including fuel, ignition and cylinder compression. Fuel quality can be known from the octane number of the fuel, the higher the octane number, the better the fuel. To increase the octane number can be done by adding ethanol to the fuel mixture, according to what was revealed by (Samuel Raja et al., 2015) "Engine tests with various blend ratios of ethanol in gasoline have shown that E10 increases the engine power by 5 percent and the octane number increased by 5 percent for each 10 percent ethanol added " (Raja et al. 2015). In line with what was revealed (Samuel Raja et al., 2015) " Addition of ethanol to unleaded gasoline results in an increase in octane number by 5 units for each 10\% ethanol addition. He also stated that 10\% ethanol in gasoline and fuel additives improved the engine power by 5\%" (Palmer, 1986).

\section{Price of ethanol vs. Decrease in fuel consumption}

The results of a survey of researchers regarding ethanol prices in several regions will be used to analyze whether the prices spent on ethanol are commensurate with the results obtained by decreasing vehicle fuel consumption. The price of ethanol in the Surakarta area is above Rp. 100,000, for ethanol with a content of $96 \%$, while for ethanol with levels $>98 \%$, it ranges from more than Rp. 900,000, -. Ethanol prices in Jogjakarta averaged Rp. 60,000 - for ethanol at $96 \%$.

When looking at the fuel consumption data above, we take the lowest range of ethanol additions to fuel is $15 \%$ ethanol and $85 \%$ fuel, while the lowest price for an ethanol liter is IDR 60,000, then in one liter of fuel mixture (pertalite) and 15\% ethanol requires funds of around Rp. 15,630, -. Even though the addition of $15 \%$ ethanol to pertalite only increases the octane number from 90 to 96.75 it approaches the octane number of the pertamax turbo whose 98 octane number is only Rp.12,250, -.

\section{CONCLUSION}

The addition of ethanol does reduce the level of fuel consumption, however, if viewed from an economic perspective, the addition of ethanol has actually caused the purchase price of fuel to increase, this will certainly hinder the growth of the desire to use ethanol as an alternative source of fuel substitute by the people of Indonesia.

\section{REFERENCES}

BPH Migas. (nd). Downstream Oil and Gas Regulatory Agency.

F. H Palmer, MI MechE, Vehicle performance of gasoline containing oxygenates, C319 / 86, pp. 33-46, 1986.

Gaikindo. (2018). Gaikindo, 4-5.

Muhsin, Wijayanto, DS, \& Bugis, H. (2017). THE EFFECT OF ADDITION OF ETHANOL AND HEATING OF FUEL THROUGH LONGITUDINAL FLATED PIPES ON TOYOTA KIJANG FUEL CONSUMPTION, 2 (1).

Ode, L., \& Wahid, MA (1982). Use of Bio-Ethanol as a Premium Material, 63-74.

Okoli, C., \& Schabram, K. (2011). A Guide to Conducting a Systematic Literature Review of Information Systems Research. Ssrn , 10 (2010). https://doi.org/10.2139/ssrn.1954824

Sakthivel, P., Subramanian, KA, \& Mathai, R. (2018). The Indian scenario of ethanol fuel and its utilization in the automotive transportation sector. Resources, Conservation and Recycling , 132 (September 2017), 102120.https://doi.org/10.1016/j.resconrec.2018.01.012

Samuel Raja, A., Valan Arasu, A., \& Sornakuma, T. (2015). Effect of gasoline - ethanol blends on performance and emission characteristics of a single cylinder water cooled motor bike the engine. Journal of Engineering Science and Technology , 10(12), 1540-1552.

Sujono, A., \& Kristiawan, B. (2009). Abstract :, 8 (September), 114-117.

Wijayanto, DS, Rohman, N., Hadisaputro, R., Bugis, H., \& Agung Pambudi, N. (2017). Preliminary experiment on fuel consumption and emission reduction in engine using blended bioethanol - gasoline and radiator tube heater. International Journal of Sustainable Engineering , 10 (2), 115-122. https://doi.org/10.1080/19397038.2016.1264497 
Wiratmaja, IG, Kusuma, IGBW, \& Winaya, INS (2011). Making Second Generation Ethanol by Utilizing Eucheuma Cottonii Seaweed as Raw Material. Chakra Mechanical Engineering Scientific Journal , 5 (1), 75-84. 